\title{
Leszek KARSKI*
}

\section{Hiszpańskie i niemieckie osiągnięcia w rozwoju energetyki odnawialnej. Aspekt prawny}

Z dniem 1 maja 2004 r. Polska przystąpiła do struktur Unii Europejskiej. Z faktu tego można wyciągnąć szereg pozytywnych i negatywnych konsekwencji dla naszego kraju. Jednak bezsprzecznie należy stwierdzić, że bereficjentem poszerzenia Unii Europejskiej będzie polski sektor energetyki odnawialnej. Wynika to zarówno ze wspólnotowej polityki energetycznej, jak i z wspólnotowych aktów prawnych.

Dostosowanie polskiego prawa do wymagań prawa wspólnotowego w obszarze energetyki odnawialnej następuje stopniowo. Wspomnieć należy w tym miejscu o ustawie z dnia 24 lipca 2002 r. o zmianie ustawy Prawo energetyczne ${ }^{1}$, czy ustawie z dnia 2 kwietnia 2004 r. o zmianie ustawy - Prawo energetyczne oraz ustawy - Prawo ochrony środowi$\mathrm{ska}^{2}$. Jednak warto zauważyć, iż osiagnięcie celów krajowych oraz celów wspólnotowych w omawianym zakresie wymaga dalszych zmian w prawie polskim. Dlatego też niezmiernie ważne jest skupienie uwagi polskiego prawodawcy na osiaggnięciach innych państw członkowskich. Szczególnie interesujące wydają się mechanizmy prawne i ich rezultaty $w$ Hiszpanii i Niemczech.

\section{Hiszpańskie osiągnięcia}

Hiszpania jest jednym ze światowych potentatów w pozyskiwaniu energii ze źródeł odnawialnych. Silnym bodźcem dla wzmożenia intensywności działań publicznych na rzecz rozwoju energetyki odnawialnej byjl i jest wzrost ekonomiczny, a co za tym następuje zwiększające się zapotrzebowanie na energię. Hiszpania nie należy do krajów zasobnych w

\footnotetext{
Instytut Ekologii i Bioetyki, UKSW w Warszawie.

Ustawa z dnia 24 lipca 2002 r. o zmianie ustawy - Prawo energetyczne (Dz.U. Nr 135, poz.1144).

2 Ustawa z dnia 2 kwietnia 2004 r. o zmianie ustawy - Prawo energetyczne oraz ustawy Prawo ochrony środowiska (Dz.U. Nr 91, poz. 875).
} 
duże złoża własnych konwencjonalnych surowców energetycznych. Import nośników i energii jest zbyt kosztowny dla gospodarki krajowej. Dlatego też kolejne rządy skupiały się na poszukiwaniu rozwiązań alternatywnych. Początkowo nastąpił rozwój energetyki nuklearnej. Obecnie elektrownie wykorzystujące paliwa jądrowe dostarczają około $25 \%$ całości wytwarzanej energii. Jednak społeczeństwo odnosi się niechętnie do rozwoju tego sektora ${ }^{3}$. Dlatego też począwszy od lat osiemdziesiątych $w$ Hiszpanii nastąpił znaczny rozwój wykorzystania zasobów odnawialnych. Sprzyjają temu zarówno warunki geograficzne, jak i konsekwentna polityka państwa oraz krajów związkowych.

Analiza obecnie obowiązujących rozwiązań hiszpańskich w zakresie energetyki odnawialnej sprowadza się do rozważenia trzech szczebli ustawodawstwa. Po pierwsze są to regulacje unijne, które są wspólne dla wszystkich państw członkowskich.

Kolejnym poziomem jest ustawodawstwo ogólnokrajowe. Prawodawca państwowy ustanawia środki adekwatne do specyfiki hiszpańskiej oraz do celów wyznaczonych przez Unię Europejską. Art. 149 ust 1 Konstytucji Hiszpańskiej zapewnia wyłączne kompetencje państwa w zakresie regulowania podstaw w obszarze ogólnego planowania działalności gospodarczej oraz gospodarki energetycznej. Regulacją ogólnopaństwowa stanowi podstawę systemu wsparcia oraz fundament podejmowania działań publicznych w omawianej materii. Ponadto art. 149 ust 1 pkt 22 zasadniczej ustawy hiszpańskiej stanowi, iż państwo ma wyłączne kompetencje w regulacji i planowaniu oraz koncesjonowaniu $w$ dziedzinie zasobów wodnych, jeżeli woda znajduje się na terenie co najmniej dwóch prowincji oraz wydawania pozwoleń dla elektrowni, jeżeli oddziaływują one na inną prowincje, aniżeli kraj związkowy usytuowania instalacji. Jednak w hiszpanskiej Konstytucji podkreślono, iż sprawy bezpośrednio nie zastrzeżone do kompetencji państwa mogą być powierzone prowincjom ${ }^{4}$. $Z$ tego też powodu kompetencje $w$ dziedzinie odnawialnych źródeł energii przeważnie należą do autonomicznych wspólnot ${ }^{5}$. Dlatego trzeci poziom regulacji stanowią przepisy lokalne. Są one przyjmowane przez władze lokalne w 17 prowincjach Hiszpanii ${ }^{6}$. Prawodawstwo autonomicznych wspólnot posiada zatem w omawianym przypadku szczególne znaczenie dla faktycznej realizacji polityki państwa $w$ danym kraju autonomicznym. Wiele prowincji wykorzystało sprzyjające warunki geograficzne ${ }^{7}$. Wypada wspomnieć o

3 W. GŁOĆKO, Ksztattowanie rynku energii odnawialnej w' Europie. Rynek energetyki wiatrow'ej w Hiszpanii, CzE 2002r., nr 9, s. 8.

4 Art 149 ust 3 Konstytucji Hiszpanii.

5 Altener Programme. Contract Nş. 4.1030/E/96-008. Final Report of the Ener-Iure Project. RES' legislation in Spain, 1998, s. 128 i n.

6 Market Access, www.tradeport.org/ts/countries/spain/isa/isar0016.html - z dnia 06.10.2002.

7 Wind energy in Spain, Renewable Energy Journal Nr 9/1999, s. 4 i n. 
ustawodawstwie Galicji, Navarry czy Murcji. W przepisach krajowych zapewniono silne wsparcie dla poszczególnych rodzajów energetyki odnawialnej $j^{8}$.

Prawodawca uznał, iż odpowiednie mechanizmy powinny być zawarty nie tylko na szczeblu systemu ogólnokrajowego. Stwierdzono, iż przede wszystkim ustawodawcy krajów związkowych oraz ich działania mogą najszybciej i najbardziej efektywnie doprowadzić do zwiększenia udziału czystej energii. To właśnie dzięki prostemu zastosowaniu w praktyce zasady subsydiarności, od początku lat dziewięćdziesiątych następuję prosperita odnawialnych źródeł energii, w szczególności w zakresie wykorzystania siły wiatru. Oczywiście podstawy systemu wsparcia znajduja się $w$ ogólnokrajowych regulacjach prawnych, natomiast prowincjom pozostawiono dużą autonomie w promocji odnawialnych źródeł energii.

\section{Ogólnopaństwowy dorobek prawny Hiszpanii}

Odnawialne źródła energii zostały objęte szczególnym reżimem od roku 1980, kiedy to wydano ustawę Prawo efektywności energetycznej ${ }^{9}$. Akt ten był odpowiedzią na drugi kryzys paliwowy. Prawodawca hiszpański ustanowił $w$ nim ramy racjonalnego użytkowania energii w przemyśle. Istotne postanowienia odnosiły się również do zmniejszenia zależności od importowanych nośników energii oraz importowanej energii. Praktyczne zastosowanie przepisów wspomnianej ustawy doprowadziło do zwiększenia własnej produkcji energii oraz do powstawania elektrowni wodnych. Prawodawca hiszpański wydał wiele aktów wykonawczych odnoszących się do energetyki odnawialnej. Na wspomnienie zasługują dwa nieobowiązujące już dekrety królewskie. W 1982 r. wydano pierwszy $z$ nich ${ }^{10}$. Odnosił się on do wsparcia autoprodukcji, czyli wytwarzania energii na własne potrzeby. W grudniu 1994 r. opublikowano dekret królewski ${ }^{11}$, którego zakres obejmował regulację kogeneracji oraz instalacji produkujących czystą energię, w szczególności energetykę wodną. W akcie tym ujęto podstawowe zasady wsparcia wykorzystania zasobów odnawialnych.

\footnotetext{
Spain Renewable Energy Policy, Madrid 2000, IDAE, s. 5 i n.

The Spanish Law 82/1980 on Energy Conservation, 30.12.1980.

Royal Decree $907 / 1982$ of 2 April on the promotion of the self generation of electricity.

11 Royal Decree 2366/1994 of 9 December relating to the production of electricity by hydroelectric and cogeneration plants and any other plants using renewable energy sources Spanish Official Gazette no. 313 of 31 December 1994.
} 
Od 1 stycznia 1998 r. zaczęła obowiązywać ustawa o sektorze elektroenergetycznym ${ }^{12}$. Akt ten wprowadza liberalizację tego newralgicznego segmentu gospodarki narodowej, zgodnie z postanowieniami dyrektywy Unii Europejskiej 92/96/EC ${ }^{13}$. Jednym z celów ramowego aktu elektroenergetycznego ${ }^{14}$, jest między innymi włączenie do przychodów producentów czystej energii korzyści środowiskowych i społecznych, które są osiągane dzięki wykorzystaniu odnawialnych źródeł energii. Omawiając sytuację odnawialnych źródeł energii pod kątem unormowań hiszpańskiego prawa, należy pokusić się o uwagę, iż rozwój omawianego zagadnienia jest ściśle związany z postępującą liberalizacją rynku energetycznego. Państwo rezygnuje z części szczególnych regulacji w stosun$\mathrm{ku}$ do tego strategicznego sektora i wprowadza reżim prawny, który gwarantuje objęcie branży energetycznej zasadami wolnej gospođarki. Przede wszystkim oznacza to, iż odbiorca końcowy będzie uprawniony do zakupu energii od wybranego przez siebie kontrahenta. Od $2004 \mathrm{r}$. $100 \%$ odbiorców hiszpańskich przysługuje powyższe uprawnienie ${ }^{15}$. $\mathrm{Z}$ pewnością pełne otwarcie rynku i demonopolizacja pozytywnie wpłynie na dalszy wzrost udziału czystej energii w bilansie Hiszpanii, na co wskazują ekspertyzy przeprowadzone przez hiszpański Instytut Poszanowania Energii i Dywersyfikacji (IDAE) ${ }^{16}$.

W ustawie o sektorze elektroenergetycznym, ustanowiono specjalne regulacje odnoszące się do producentów czystej energii ${ }^{17}$. Zatem przedsiębiorstwa, które wytwarzają energię elektryczną $w$ elektrowniach wiatrowych, ogniwach fotowoltaicznych, kolektorach słonecznych oraz elektrowniach korzystających $z$ biomasy otrzymały specjalne uprawnienia, $o$ ile ich moc nie przekracza $50 \mathrm{MV}$. Ponadto prawodawca hiszpański uznal za stosowne objąć systemem wsparcia małą energetykę wodną, czyli elektrownie wodne o mocy do 10 MV. Przy ich wykorzystaniu przewiduje się następujące mechanizmy wsparcia: zagwarantowanie dostępu do sieci przesyłowych, uproszczenie procedur przed organami administracji w zakresie inwestowania i prowadzenia działalności, rejestrowanie

12 The Spanish Law 54/1997 of November 27th 1997 on the Spanish Electricity Sector.

13 Directive 96/92/EC of the European Parliament and of the Council of 19 December 1996 concerning common rules for the internal market in electricity, OJ L 027, 30/01/1997.

14 I. PALOMINO, A Strategy for renewable energy sources, materialy konferencyje, First annual European Energy and Transport Conference, Theme 1 Sustainable Development and Security 2001.

15 R. GILECKI, Liberalizacja rynku energii elektrycznej w krajach Unii Europejskiej, Gospodarka Paliwami i Energią, Nr 4/2002, s. 2-7.

16 Spain Renewable Energy Policy, Madrid 2000, IDAE, s. 7 i n.

17 W art. od 27 do 31 The Spanish Law 54/1997 of November 27th 1997 on the Spanish Electricity Sector określono podstawowe zasady tzw. specjalnego systemu opartego na wykorzystaniu źródel energii odnawialnej. 
źródeł $\mathrm{w}$ specjalnym rejestrze administracyjnym ${ }^{18}$, zapewnienie zakupu po określonej cenie albo po cenie zmiennej.

Organem, który posiada kompetencje $\mathrm{w}$ zakresie odnawialnych źródeł energii jest Dyrektoriat generalny do spraw polityki energetycznej i wydobywczej ${ }^{19}$. Natomiast agencją państwową, której celem jest wspieranie naukowców i inwestorów w zakresie wykorzystania energetyki odnawialnej jest IDAE. Ponadto Hiszpania posiada około 30 agencji regionalnych i lokalnych, które zajmują się rozważaną problematyką.

Hiszpańskie regulacje prawne odnoszące się do energetyki odnawialnej pozostaja pod dużym wpływem międzynarodowych zobowiązań, zwłaszcza $w$ zakresie zmniejszenia emisji gazów cieplarnianych. Hiszpania, co prawda uzyskała prawo do $15 \%$ wzrostu emisji gazów objętych protokołem z Kioto w stosunku do poziomu z 1990 r. Jednak już w 1999 r. przekroczono ten próg o $6 \%{ }^{20}$. Dlatego też energetyka odnawialna jest istotnym elementem wypełnienia zobowiązań $z$ Kioto. $W$ dekrecie królewskim z dnia 6 kwietnia $2001 \mathrm{r}$. wydanym przez Ministra Środowiska ${ }^{21}$ powołano Hiszpańskie Biuro Zmian Klimatu ${ }^{22}$, które ma za zadanie promować oraz koordynować działania związane z zapobieganiem zmianom klimatycznym. Szczególną wagę przywiązano do zwiększenia wykorzystania zasobów odnawialnych.

Ważnym czynnikiem rozwoju sektora energii odnawialnej, na szczeblu krajowym, stały się w Hiszpanii przede wszystkim długoterminowe strategie. Począwszy od Pierwszego planu odnawialnej energii z 1986 r. wyznaczano aktywna promocję zarówno wykorzystania odnawialnych źródel, jak i określono wparcie dla produkcji komponentów "czystych" elektrowni. Kolejny plan z 1989 r. skierowany był na rozpowszechnianie i zastosowanie projektów energetyki odnawialnej ${ }^{23}$. Narodowy Plan Energetyczny na lata 1991-2000 ustanowił system zachęt dla kogeneracji, czyli wspólnego wytwarzania ciepła i prądu, oraz produkcji energii elektrycznej z zasobów odnawialnych. Ustalono cele udziału czystej energii elektrycznej $\mathrm{w}$ całkowitym bilansie elektroenergetycznym na $4,5 \% \mathrm{w}$ 1994 i 10\% w 2000 r. Aktualnym dokumentem planistyczno-strategicznym w zakresie OŹE jest Plan Promocji Energii Odnawialnej 2000-201024,

\footnotetext{
18 ENER-IURE Phase III Analysis of the legislation regarding renewable energy sources in the E.U. Member States. RES legislstion in Spain, Bonn 2002.

19 Review of Energy Efficiency CO2 and Price Policies and Measures in EU countries and Norway in 2001, ENERDATA 2002, s. 38.

20. Review of Energy Efficiency $\mathrm{CO} 2$ and Price Policies and Measures in EU countries and Norway in 2001, ENERDATA 2002, s. 38.

${ }^{21}$ Royal Decree $376 / 2001$ of the Environment Ministry approved restructuring plans 06.04.2001.

22 Hiszp. Oficina Espańola de Cambio Climático.

23 http://www.eurorex.com/viewcountry.asp?viewL3=N\&countryID=27

24 Hiszp. Plan de Fomento de las Energías Renovables 2000-2010.
} 
który został przyjęty przez Radę Ministrów 30 grudnia 1999 r. Ogólnym dążeniem państwa hiszpańskiego jest osiągnięcie $12 \%$ udziału energii uzyskiwanej $\mathrm{z}$ odnawialnych źródłach energii $\mathrm{w}$ ogólnej konsumpcji energii $^{25}$ oraz $29,4 \%$ udział czystej energii elektrycznej w ogólnej konsumpcji elektryczności w 2010 r. Plan na lata 2000-2010 zakłada zwiększenie wysiłku w kierunku rozwoju energetyki odnawialnej ${ }^{26}$.

\section{Hiszpański system wsparcia}

Hiszpania charakteryzuje się dużą liczbą mechanizmów wspomagających rozwój energetyki odnawialnej. Niezwykle rozbudowany system wsparcia wynika zarówno $z$ założenia, iż koszty powinny być rozłożone jak najbardziej równomiernie oraz $\mathrm{z}$ założenia, iż pomoc powinna być wykorzystana jak najbardziej efektywnie. Podstawę tego systemu stanowią odpowiednie postanowienia powyżej wymienionych regulacji ogólnokrajowych oraz akty prowincji.

Analizując zagadnienie wsparcia szczególną uwagę należy poświęcić dekretowi królewskiemu z 23 grudnia 1998 r. w sprawie produkcji energii elektrycznej $\mathrm{z}$ zasobów odnawialnych, odpadów oraz $\mathrm{w}$ skojarzeniu $^{27}$. Akt ten szczegółowo wylicza urządzenia o jakiej mocy i źródłach zasilania mogą ubiegać się o dotacje i innego rodzaju pomoc finansową. Dotyczy to przede wszystkim urządzeń o mocy poniżej $50 \mathrm{MW}$, które jako główne źródło energii wykorzystuja: słońce, wiatr, ciepło ziemi, siłę wody, biomasę, odpady. Muszą one jednak przejść procedurę rejestracji. Hiszpania podobnie jak Niemcy i Dania wprowadziła procedury wydawania uprawnień dla instalacji wykorzystujących energię odnawialną, przez państwo lub też odpowiednie władze lokalne, w zależności od ich kompetencji. Zasadniczo $\mathrm{w}$ omawianym kraju uprawnienie to przysługuje autonomicznym prowincjom. Ich organy, na podstawie dostarczonych informacji o danym źródle, decyduja o wpisie do odpowiedniego rejestru. Wpis do rejestru stanowi konieczny wymóg dla uzyskania przewidzianych prawem hiszpańskim premii za czystą energię. Warto zaznaczyć, iż władze lokalne zostały upoważnione do wypowiadania się w kwestii dopuszczalności zbudowania konstrukcji, działania źródła oraz istotnej modernizacji $\mathrm{i}$ innych działań związanych $\mathrm{z}$ funkcjonowaniem urządzeń, jak również oceny możliwości ich działania.

\footnotetext{
25 W planie są dwa scenariusze, ambitniejszy zaklada przytoczony udział $12 \%$, drugi scenariusz zakłada 11,2\% udziału czystej energii w 2010 r. w ogólnej konsumpcji eenergii.

26 Eergy Poliecies of IEA Countries. Spain 2001 Review, Paris 2001, IEA, s. 107-114.

27 Royal Decree RD 2818/1998, 23.12.1998. Official State Gazette Nr 312.
} 
Natomiast w sytuacji, w której źródła znajdują się na terenie więcej niż jednej prowincji lub oddziałują na kraj związkowy, w którym nie jest usytuowane źródło, zagadnienia związane $\mathrm{z}$ wydaniem odpowiedniego pozwolenia są rozpatrywane na szczeblu ogólnokrajowym przez Dyrektora Generalnego do spraw polityki energetycznej i wydobywczej.

Procedura rejestracji źródła ulega zakończeni, kiedy do dostarczonych dokumentów charakteryzujących źródło oraz podania o rejestrację dołączona zostanie również kopia umowy między właścicielem instalacji produkujących energię a dystrybutorem. Umowa taka powinna być podpisana co najmniej na okres pięcioletni. W jej treści powinno być zawarte określenie wzajemnych relacji zarówno technicznych jak i ekonomicznych. Prawodawca hiszpański pokusił się również o wyliczenie w dekrecie z 1998 r. podstawowych kwestii, które muszą być zawarte w umowie, takie jak, miejsce połączenia, charakterystykę jakościową i ilościową dostarczanej energii, warunki w jakich nadwyżka energii nie może być przyjęta przez sieć, oraz prawa i obowiązki producenta $\mathrm{w}$ jego relacjach $z$ dystrybutorem.

Istotnym postanowieniem, mającym duże znaczenie przy omawianym zagadnieniu jest obciążenie kosztami związanymi z podłączeniem oraz konieczną modernizacją sieci właściciela instalacji.

Kolejne zagadnienie, to sposób ustalania ceny za czystą energię płaconą producentom. W Hiszpanii mamy do czynienia $z$ mieszanym mechanizmem cenowym. Oznacza to, iż producenci zielonej energii posiadaja możliwość wyboru pomiędzy sprzedażą swojego towaru po cenach stałych - ustalonych przez prawodawcę, bądź po cenach rynkowych uzupełnionych o premię ${ }^{28}$. Istotnym elementem wsparcia rozwoju energetyki odnawialnej jest szczegółowe określenie przez prawodawcę hiszpańskiego sposobu liczenia opłat za energię ze źródeł odnawialnych. Stawka za czystą energię, wytwarzaną w źródłach, które znajdą się we wspomnianym rejestrze, jest zróżnicowana i zależy od zastosowanej technologii i mocy produkcyjnej źródła.

Hiszpański system określenia minimalnych cen jest oparty na sumie następujących elementów: cenie rynkowej za energię, premii oraz otoczenia energetycznego, które może wpływać pozytywnie albo negatywnie. Producenci energii ze źródeł odnawialnych mogą otrzymywać tzw. cenę ustaloną, która nie zależy od godzin jej dostarczenia. Dla tego rodzaju instalacji o mocy po wyżej 50MW ustanowiona została premia w wysokości 0,6 Eurocenta/kWh ${ }^{29}$.

2* Należy jednak zauważyć, iż Hiszpania coraz mocniej skłania się w kierunku ceny wolnorynkowej uzupełnionej o premie.

29 Materiały pochodzą ze stron internetowych, www.agores.org/Publications/EnR/SpainREpolicy2000.pdf - $z$ dnia 06.10.2002. 
Polityka państwa hiszpańskiego zmierza $w$ kierunku wspomagania małych i średnich źródeł odnawialnych, rozproszonych. Konsekwencją tego jest to, iż instalacje o mocy mniejszej niż 50MW nie zostały zobowiązane do formułowania ofert rynkowych $\mathrm{w}$ przetargach, lecz są uprawnione do sprzedaży energii po cenach godzinowych uzupełnionych o premie ${ }^{30}$. Zatem wymaga podkreślenia fakt, iż tylko uprawnieni producenci energii odnawialnej mogą korzystać $z$ tego przywileju.

Kolejnym wsparciem są kredyty oraz subsydia. W Hiszpanii projekty technologiczne moga być dofinansowane nawet do $70 \%$ poniesionych kosztów a oprocentowanie pożyczek może być zredukowane o $5 \%$. Zwykle pomoc finansowa jest ustalana na podstawie programów wsparcia. $W$ Hiszpanii popierane są głównie programy odwołujące się do energii słonecznej, a przyznawane subwencje nie przekraczają $40 \%$ kosztów realizacji inwestycji. Hiszpania potrafi efektywnie wykorzystywać na cele rozwoju energetyki odnawialnej środki funduszy unijnych. Przewiduje się, iż koszty planowanej pomocy publicznej $w$ najbliższych latach $w$ zakresie energetyki odnawialnej w $73 \%$ zostaną pokryte $\mathrm{z}$ funduszy unijnych ${ }^{31}$.

Oprócz regulacji krajowej prawodawca hiszpański dodatkowo upoważnił również rządy lokalne do ustanawiania dodatkowych środków na dofinansowanie omawianego podsektora energetycznego.

Jeden $\mathrm{z}$ ważniejszych problemów, który wymaga ustawowych rozwiązań to podłączenie danego urządzenia do sieci oraz jego dostępu do rynku. Wynika to z obowiązku nabycia przez operatorów sieci przesyłu energii pozyskiwanej ze źródeł odnawialnych. W Hiszpanii jak powyżej wspomniano przewidziano, iż umowy między producentami, a operatorami sieci, zawierane są na co najmniej 5 lat.

\section{Rezultaty działań podjętych przez Hiszpanię}

W Hiszpanii wpływ na rozwój energetyki odnawialnej miała duża zależność od importu energii. Obok prac nad nowymi technologiami wykorzystania odnawialnych źródeł energii znaczne wysiłki były kierowane na tzw. "czyste spalanie węgla”, czyli produkcje energii lub ciepła z węgla przy minimalnym wpływie na środowisko. Wykorzystanie innych lokalnych zasobów sprowadzało się do niedawna do tradycyjnego spalania biomasy, wykorzystywanego głównie w sekatorze mieszkaniowym

30) The Ener - Iure Project. Stock - taking and analysis of the present technical and legal sittlation of renewable energy sources in Europe. Phase III. 30 June 2002. Final Report, Electricity: Technical Recommendations, www.jrc.es/cfapp/eneriure/Reports/Final\%20reports-Electricity-TR-EIII.pdf $-\mathrm{z}$ dnia 06.10.2002.

31 Energy Poliecies of IEA Countries. Spain 2001 Review, Paris 2001, IEA, s. 110. 
oraz do zagospodarowania siły rzek. Rozbudowa sieci przesyłowych oraz strategia większego zaspokajania potrzeb energetycznych poprzez elektryfikację, spowodowała wzrost zapotrzebowania na zasoby energetyczne, co przy drogim imporcie i zachętach państwa, spowodowało wzrost wykorzystania odnawialnych źródeł energii. Szczególnie rozwinął się rynek energii wiatrowej. Przyczyniły się do tego zarówno wsparcie na szczeblu ustawodawstwa krajowego, jak i regulacje w kilku prowincjach. W szczególności Galicja i Navarra zapewniły sprzyjające warunki ekonomiczno-prawne dla rozwoju wspomnianego rodzaju energetyki odnawialnej ${ }^{32}$. Hiszpania opowiedziała się za przyznaniem szerokich kompetencji prowincjom $\mathrm{w}$ zakresie regulacji energetyki odnawialnej. Władze wspólnot autonomicznych posiadaja lepsze rozeznanie o warunkach i możliwościach rozwoju wykorzystania lokalnych zasobów odnawialnych. Będąc bliżej obywatela działają efektywniej. Taki zabieg przyniósł Hiszpanii znaczne efekty we wzroście udziału czystej energii. Tak więc, kompetencje lokalnych władz w połączeniu ze wsparciem prywatnych i publicznych przedsiębiorstw podejmujących inicjatywę rozwoju nowych technologii ${ }^{33}$, przy stosunkowo niskich nakładach ${ }^{34}$, dało bardzo dobre efekty. Hiszpania do niedawna była trzecim producentem energii $\mathrm{z}$ siły wiatru na świecie ${ }^{35}$. Jednak dzięki najwyźszemu procentowemu przyrostowi $w$ tym rodzaju energii odnawialnej, Hiszpania prześcignęła Stany Zjednoczone $\mathrm{w}$ produkcji energii $\mathrm{z}$ siły wiatru i obecnie zajmuje drugie miejsce na świecie ${ }^{36}$.

Przedstawiciele nauki hiszpańskiej oraz przedstawiciele władz podkreślaja, iż bereficjentem oferowanej pomocy publicznej dla czystej energii jest całe społeczeństwo, które czerpie korzyści z wykorzystywania energii pozyskiwanej w oparciu o źródła odnawialne. Dlatego też takie uzasadnienie pozwala na określenie $w$ prawie hiszpańskim stabilnych mechanizmów wsparcia dla podsektora energetyki odnawialnej.

\section{Niemiecki dorobek}

Niemiecki rząd federalny, biorąc pod uwagę ochronę środowiska oraz klimatu, jak również zmniejszenie zależności od importu oraz zabez-

\footnotetext{
32 Spain Renewable Energy Policy, Madrid 2000, IDAE, s. 6.

33 The Ener - Iure Project. Stock - taking and analysis of the present technical and legal situation of renewable energy sources in Europe. Phase III. 30 June 2002. Final Report, Subsidies: Technical Recommendations www.jrc.es/cfapp/eneriure/Reports/Final\%o20reports-Subsidies-TR-EIII.pdi - z dnia 06.10.2002.

34 Porównując wydatki Niemiec.

35. J. WHITMAN, Spain is a world leader in wind energy, The Business Link, $\mathrm{Nr} 2 / 2001 \mathrm{r}$., s. $10-11$.

36 Trzy czwarte elektryczności wiatrowej produkuje się w UE, Gazeta Wyborcza, 05.03.2003.
} 
pieczenie zasilania, postawił sobie za cel osiągnięcie w 2010 r. 12,5\% udziału czystej energii. Cel ten związany jest $z$ koniecznością wypełnienia zobowiązań międzynarodowych Republiki Federalnej Niemiec w zakresie zmniejszenia emisji gazów cieplarnianych o $21 \% \mathrm{w}$ stosunku do roku bazowego 1990. Obecny udział czystej energii pochodzi w przeważającej części z tradycyjnego potencjału wody wielkich zbiorników. Ich technologiczne możliwości rozwoju zostały w dużej mierze wyczerpane. Dlatego postawiony przez Unię Europejską cel w postaci $21 \%$ udziału czystej energii elektrycznej w calkowitej wspólnotowej konsumpcji $2010 \mathrm{r}$. może być zrealizowany poprzez zwiększenie obecnie wykorzystywanego potencjału zasobów energii uzyskiwanej $\mathrm{z}$ wiatru, promieni słonecznych, biomasy.

Państwo niemieckie $w$ zakresie promocji energetyki odnawialnej $w$ pełni wykorzystuje zasadę wyższego standardu. Oznacza to, iż prawo niemieckie nakłada wyższe obowiązki w stosunku do przedsiębiorstw energetycznych oraz silniej wspomaga rozwój wykorzystania zasobów odnawialnych, aniżeli wymaga tego prawo wspólnotowe.

Warto zauważyć, iż początkowo Komisja Europejska uznała postanowienia aktów niemieckich odnoszących się do odnawialnych źródeł energii, za wprowadzanie niedozwolonej pomocy publicznej. Jednak stanowisko Trybunału Europejskiego z 2001 r. obaliło hipotezę o niezgodności z prawem traktatowym niemieckiego systemu cen minimalnych. $W$ orzeczeniu z 13 marca 2001 r. Europejski Trybunał Sprawiedliwości stwierdzil, iż przepisy nakładające na przedsiębiorstwa energetyczne obowiązek zakupu czystej energii elektrycznej po cenie wyższej od ceny rynkowej energii elektrycznej nie naruszają postanowień Traktatu o ustanowieniu Wspólnoty Europejskiej, które odnoszą się do wolnego przepływu dóbr oraz dozwolonej pomocy państwowej.

Z powyżej wspominanych powodów Rząd niemiecki doszedł do wniosku, konieczna jest nowa regulacja i wprowadzenie silniejszych mechanizmów wsparcia do prawa niemieckiego. Dlatego też w 2000 r. uchwalono nowy akt dotyczący odnawialnych źródeł energii. Ustawa ta przewiduje wspieranie elektryczności uzyskiwanej $\mathrm{z}$ energii wodnej, energii wiatrowej, energii słonecznej, ciepła geotermalnego, gazu wysypiskowego, gazu z oczyszczalni ścieków, gazu kopalnianego oraz biomasy. Prawodawca niemiecki ograniczył jednak krąg źródeł uprawnionych do wsparcia. Zatem mechanizmy promocji określone przez akt z 17 marca 2000 r. nie są skierowane do:

- elektrowni wodnych, elektrowni wykorzystujących gaz wysypiskowy, gaz z oczyszczalni ścieków, instalacji wykorzystujących energię słoneczną montowanych na konstrukcjach, obiektach, budynkach, których pierwotnym celem nie jest produkcja energii elektrycznej - jeżeli ich moc zainstalowana jest większa niż $5 \mathrm{MW}$; 
- pozostałych źródeł wykorzystujących energię słoneczną, jeżeli ich moc przekracza $100 \mathrm{~kW}$;

- elektrowni wykorzystujących biomasę, jeżeli mają większą moc niż 20 MW.

Takie posunięcie jest uzasadnione tym, iż większe elektrownie, wykorzystując zasadę ekonomii skali, są konkurencyjne w stosunku do paliw konwencjonalnych. Zatem nie wymagają objęcia ich systemem wsparcia. Natomiast ograniczenia odnoszące się do urządzeń wykorzystujących energię słoneczną są podyktowane tym, aby nie promować dużych instalacji przesłaniających przestrzeń i niekorzystnie wpływających na krajobraz. Należy podkreślić, iż w przypadku instalacji produkujących energię dzięki sile wiatru, ciepłu geotermalnemu bądź gazowi kopalnianemu, nie wprowadzono ograniczeń, które byłyby uzależnione od wielkości mocy zainstalowanej.

Prawodawca wprowadził również ograniczenia podmiotowe dla uprawnień do korzystania z systemu wsparcia. Mechanizmy wsparcia nie są skierowane do odnawialnych źródeł energii, w których państwo lub kraje federalne posiadają powyżej $25 \%$ udziału we współwłasności.

\section{Obowiązki przedsiębiorstw sieciowych}

Na tle obecnych postanowień prawa niemieckiego można mówić o kilku rodzajach obowiązków nałożonych na operatorów sieci, które zarazem stanowią korelat uprawnień producentów energii elektrycznej. Są to: obowiązek przesyłu, obowiązek przyłączenia producenta czystej energii do sieci, obowiązek odbioru prądu oraz zapłaty po określonej przez ustawę cenie.

Obowiązek przyłączenia do sieci producenta czystej energii ciąży na lokalnym zakładzie energetycznym, którego infrastruktura znajduje się najbliżej uprawnionej instalacji. Przyłączenie do sieci producenta energii z odnawialnych zasobów może łączyć się z koniecznością modernizacji bądź rozbudowa infrastruktury danego zakładu. Koszty z tym związane ponosi zakład energetyczny, który jest zobowiązany do przedsięwzięcia odpowiednich środków bez zbędnej zwłoki. Natomiast kosztem budowy podłączenia od źródła do istniejącej sieci został obarczony producent czystej energii.

Prawodawca niemiecki uznał za stosowne, aby przyznać odnawialnym źródłom energii priorytet $\mathrm{w}$ dostępie do sieci. Tak więc, przedsiębiorstwo sieciowe nie może powoływać się na przeciążenie sieci na skutek przesyłu energii pochodzącej $z$ konwencjonalnych albo atomowych elektrownii i odmówić pobrania czystej energii.

Obowiązek pobrania czystej energii odnosi się do całej zaoferowanej wielkości. Oznacza to, iż nie zdecydowano się na określenie wysokości 
udziału procentowego, którego osiągnięcie zwalniałoby przedsiębiorstwo energetyczne $z$ obowiązku. Wydaję się, iż taki zabieg był konsekwencją doświadczeń z funkcjonowania zapisów poprzedniej ustawy, która określała próg pięcioprocentowy.

Istotną nowością wprowadzoną przez ustawę o odnawialnych źródłach energii jest regulacja obowiązku zapłaty. Prawodawca przewidział niezwykle korzystne dla producentów rozwiązania. Określono bowiem wysokość minimalnych stawek dla energii z poszczególnych rodzajów źródeł odnawialnych. Ponadto ich wysokość jest uzależniona od wielkości mocy, lokalizacji instalacji oraz daty uruchomienia źródła. Ustalone stawki powinny obowiązywać przez okres 20 lat od dnia uruchomienia danej elektrowni ${ }^{37}$. $\mathrm{Ma}$ to zapewnić stabilność polityki państwa oraz zachęcić inwestorów.

Wysokość stawek wynagrodzeń dla producentów czystej energii została ustalona na podstawie naukowych prac. Ceny za czystą energię powinny przy prawidłowym gospodarowaniu zapewnić opłacalność przedsiębiorstwa wytwarzającego energię z zasobów odnawialnych. Jednak, ze względów racjonalnych, państwo nie gwarantuje pokrycia kosztów każdego urządzenia.

Postanowienia ustawy z 29 marca 2000 r. zmierzają do obciążenia wszystkich zobowiązanych przedsiębiorstw w równym stopniu kosztami zakupu uprzywilejowanej energii. Do 31 marca każdego roku zobowiązane przedsiębiorstwa powinny określić udział czystej energii w ich zakupach. Następuje obliczenie średniego udziału dla wszystkich zobowiązanych przedsiębiorstw. W sytuacji, w której dany operator sieciowy zakupił większą ilość czystej energii, aniżeli średni udział, jest on uprawniony do odsprzedaży nadwyżki operatorowi, który nie osiągnął tegoż przeciętnego wskaźnika.

Należy pamiętać, iż zobowiązane przedsiębiorstwa energetyczne nie otrzymują z tytułu wykonywania zakupów energii z OZE żadnych rekompensat. Zatem ostatecznie cena zakupu po preferencyjnych stawkach obciąża odbiorcę finalnego. Ponadto część odbiorców, którzy są nastawieni proekologicznie może wybrać wyższy procent udziału czystej energii w konsumowanej przez siebie elektryczności.

Wszelkie sprawy sporne, które powstaną pomiędzy właścicielem instalacji a przedsiębiorstwem energetycznym są rozstrzygane przez specjalnie powołane do tego biuro, przy Ministrze Gospodarki i Technologii.

\section{Inne niemieckie mechanizmy wsparcia energetyki odnawialnej}

Na niemiecki system wsparcia składają się również inne zasadnicze elementy. Po pierwsze należy wspomnieć o ulgach podatkowych przy-

37 Wyjątek stanowią elektrownie wodne i wiatrowe. 
znanych ustawą o podatku od przychodów osobistych. Na mocy jej postanowień zostało wydane rozporządzenie o egzekwowaniu podatku od przychodów. Powyższa regulacja podatkowa określa dodatkowe odliczenia od podstawy opodatkowania części środków przeznaczonych bezpośrednio w celu pokrycia kosztów inwestycji w odnawialne źródła energii dostarczające ciepło lub energię do budynków. I tak na mocy $§ 82$ wspomnianego rozporządzenia $\mathrm{w}$ ciągu pierwszego roku przedsięwzięcia oraz przez 9 kolejnych lat można odliczyć $10 \%$ wartości inwestycji. Jak zauważył Matthias Ruchser w sferze ulg podatkowych państwo wspomaga wyłącznie inwestycje osób fizycznych. Przedsiębiorstwa nie uzyskały podobnych preferencji. Ponadto czystej energii nie objęto korzystniejszą stawką podatku VAT w wysokości 7\%. Oznacza to, iż podatki pośrednie nie są instrumentem wsparcia dla rozwoju odnawialnych źródeł energii.

Po drugie $\mathrm{w}$ budżecie niemieckim wyasygnowano znaczne środki na niskooprocentowane pożyczki, kredyty oraz dotacje do określonych instalacji, które zostały przewidziane $\mathrm{w}$ programach rozwoju $\mathrm{O} \bullet \mathrm{E}$. Ministerstwo Ekonomii i Technologii przyjęło 15 marca 2002 r. nowy program określający zasady subwencjonowania. Przewidziano w nim, obok grantów finansowych dla instalacji o określonej mocy, również pożyczki o korzystnym oprocentowaniu. Niemieckie doświadczenia pokazują, iż przypadku programów ukierunkowanych na promocję konkretnych technologii w zakresie energii odnawialnej, osiągają one lepsze efekty niż przedsięwzięcia nastawione na ogólną promocję czystej energii ze wszystkich rodzajów źródeł. W Niemczech, dużym wsparciem cieszą się projekty wykorzystujące energie wiatru i słońca. W czerwcu 1989 r., rozpoczęto realizację "Programu $100 \mathrm{MW}$ z energii wiatrowej" który już w 1991 r. został rozszerzony na „Program 250 MW z energii wiatrowej”. Z kolei w grudniu 1998 r., przyjęto „program 100 tysięcy dachów pokrytych ogniwami fotowoltaicznymi. Na ten ostatni rządowy program przeznaczono 1 mld marek.

Rząd niemiecki zapowiedział na początku 2003 roku, zwiększenie subsydiów ze środków publicznych o $35 \%$ w celu zwiększenia popytu na kolektory słoneczne. W przypadku kredytów istotną rolę odgrywają Niemiecki Federalny Bank DtA oraz Niemiecki Federalny Bank KfW. Niemcy finansują również rozwój energetyki odnawialnej w krajach rozwijających się. W tym przypadku organizacją odpowiedzialną za finansowanie i udzielanie grantów jest Niemiecka Rządowa Fundacja Rozwoju oraz niektóre banki.

Dodatkowym atutem niemieckiego systemu prawnego są unormowania odnoszące się do planowania, ochrony środowiska, krajobrazu oraz budowania obiektów energetyki odnawialnej. Procedury administracyjne w Niemczech są bardziej "przyjazne” przedsiębiorcom inwestującym swoje zasoby w odnawialne źródła energii, aniżeli to ma miejsce w innych krajach europejskich. 


\section{Zalety niemieckich rozwiązań}

Mechanizmy wsparcia są silną ingerencja państwa w wolność gospodarczą. Konstrukcja pomocy dla odnawialnych źródeł energii jest $w$ Niemczech znacząco uzależniona od funduszy państwowych. Ramowa ustawa o odnawialnych źródłach ustanawia niskie koszty wejścia na rynek, głównie dzięki przerzuceniu wydatków modernizacyjnych związanych z przyłączeniem do sieci na przedsiębiorstwa przesylowe i dystrybucyjne.

Równie istotne jest zapewnienie bezpieczeństwa inwestycyjnego. Potencjalni inwestorzy powinni mieć pewność stabilności prawno-organizacyjnej. Taka stabilność została zagwarantowana przez prawodawcę niemieckiego w postaci ustawy z 2000 r. o Odnawialnych • ródłach Energii. Na szczególną uwagę zasługują charakterystyczny dla niemieckiego systemu wsparcia mechanizm cen minimalnych, których mechanizm wiąże się ściśle z zasadą „zanieczyszczający płaci”.

Wpływu nowej ustawy na ożywienie rynku czystej energii nie sposób przecenić. Według szacunków producenci energii ze źródeł odnawialnych otrzymali o 35\% większe przychody w 2001 r., aniżeli w 2000 r. pod rządami byłej ustawy ${ }^{38}$. Według obliczeń niemieckiego ministerstwa gospodarki konsekwencją ustawy, która weszła w życie 1 kwietnia $2000 \mathrm{r}$. o priorytecie odnawialnych źródeł energii był wzrost udziału czystej energii do $8 \%$ na koniec 2002 r. ${ }^{39}$.

\section{Wnioski dla Polski}

Przystapienie do Unii Europejskiej zmusza Polskę do zastanowienia się nad sposobem wdrożenia wspólnotowych postanowień $\mathrm{w}$ dziedzinie energetyki odnawialnej. Poprawka do Dyrektywy 2001/77/EC, zobowiązuje Polskę do osiągnięcia w 2010 r. wskaźnika referencyjnego w postaci $7,5 \%$ udziału energii elektrycznej wytworzonej z zasobów odnawialnych $\mathrm{w}$ całkowitej konsumpcji krajowej energii elektrycznej. Osiągnięcie wyznaczonego celu jest możliwe poprzez dalszą kontynuację modyfikacji prawa polskiego i skonstruowanie potężnego systemu wsparcia dla odnawialnych źródeł energii. Dlatego też warto skorzystać z dorobku prawnego aktualnych państw członkowskich Unii Europejskiej.

Dotychczasowe niemieckie doświadczenia pokazują, iż sprawne mechanizmy wsparcia, poparte odpowiednimi regulacjami prawnymi są

38 German renewable revenues rose 35 pct in 2001, 16 lipca 2002 r., Reuters.

$39 \mathrm{Z} 6 \%$ na koniec 1999 r., Germany wants to double renewable power - minister Werner Mueller, 12 lipca 2002 r., Reuters. 
istotnym środkiem wiodącym do osiągnięcia celu w postaci konkurencyjności czystej energii w stosunku do energii uzyskiwanej ze źródeł konwencjonalnych. Skuteczna realizacja strategii rozwoju omawianego sektora opiera się przede wszystkim na mocnych fundamentach regulacji prawnych oraz na znacznym wsparciu finansowym ze strony państwa $i$ krajów związkowych. Niemcy jako jedno z nielicznych państw poświęciły omawianemu zagadnieniu akt rangi ustawy. Należy jednak zauważyć, iż Polska nie jest tak zamożnym krajem, aby mogła bezwarunkowo wzorować się na rozwiązaniach niemieckich. Mechanizmy niemieckie są zbyt drogie, aby móc je zastosować bezpośrednio na gruncie polskim. Aczkolwiek niektóre niemieckie środki wsparcia energetyki odnawialnej warto wziąć pod uwagę podczas modyfikacji prawa polskiego. Szczególnie pomysł na połączenie interesu publicznego $\mathrm{z}$ regułami wolnej gospodarki wydaję się spełniać pokładane w nim nadzieje. Postawa niemieckich samorządów terytorialnych jest godna naśladowania.

Wydaje się, iż ze względu na bliższe uwarunkowania ekonomiczne na szczególną uwagę zasługuje dorobek prawny Hiszpanii. Zwłaszcza z tego powodu, iż kraj ten, pomimo znacznie niższych nakładów aniżeli Niemcy, znajduje się w światowej czołówce w zakresie rozwoju energetyki opartej na źródłach odnawialnych. Podstawowym plusem rozwiązań hiszpańskich jest przyznanie szerokich kompetencji $w$ zakresie regulacji omawianego obszaru prowincjom. Władze wspólnot autonomicznych posiadają lepsze rozeznanie o warunkach i możliwościach wykorzystania lokalnych zasobów odnawialnych. Będąc bliżej obywatela działają efektywniej. Kompetencje lokalnych władz w połączeniu ze wsparciem prywatnych i publicznych przedsiębiorstw podejmujących inicjatywę rozwoju nowych technologii, przy stosunkowo niskich nakładach, dały bardzo dobre rezultaty. Ponadto warto zwrócić uwagę, na to, iż hiszpański system wsparcia charakteryzuje duża liczba mechanizmów wsparcia, dzięki czemu koszty są bardziej równomiernie rozłożone pomiędzy poszczególne podmioty sektora energetycznego. 


\title{
Spanish and German achievements of development of renewable energy sector. Law aspects
}

\begin{abstract}
SUMMARY
Certainly renewable energy sector in Poland should be the beneficiary of the European Union enlargement. It results from both the energy policy and the EU law. Poland should adapt national law to the EU requirements in the field of renewable energy sources. Polish legislator may rest on other countries experience in this subject. We especially should take into consideration spanish and german measures. Spanish and german mechanisms of support for renewable energy sources at the national level are very interesting solutions. Those measures are intended to help to attain objectives such as meeting the commitments given on climate change, environmentally sustainable security of supply, and promotion of renewable energy sources.

The article is an analysis of spanish and german support systems in view of modification of polish law in the field of renewable energy sources.
\end{abstract}

